\title{
Editorial: Out of the Big Cities! The Reception of Exiles in Small Immigration Localities
}

Éditorial: Hors des grandes villes! L'accueil des exilée's dans les petits milieux d'immigration

Editorial: ¡Fuera de las ciudades! La acogida de los inmigrantes en los pequeños

lugares de migración

\section{Anouk Flamant, Aude-Claire Fourot and Aisling Healy}

\section{(2) OpenEdition}

12 Journals

\section{Electronic version}

URL: https://journals.openedition.org/remi/16908

DOI: 10.4000/remi.16908

ISSN: $1777-5418$

This article is a translation of:

Éditorial : Hors des grandes villes ! L'accueil des exilé.e.s dans les petits milieux d'immigration - URL :

https://journals.openedition.org/remi/15795 [fr]

Publisher

Université de Poitiers

Printed version

Date of publication: 30 December 2020

ISBN: 979-10-90426-67-2

ISSN: 0765-0752

\section{Electronic reference}

Anouk Flamant, Aude-Claire Fourot and Aisling Healy, "Editorial: Out of the Big Cities! The Reception of Exiles in Small Immigration Localities", Revue européenne des migrations internationales [Online], vol. 36 - n² et 3 | 2020, Online since 01 June 2021, connection on 03 January 2023. URL: http:// journals.openedition.org/remi/16908; DOI: https://doi.org/10.4000/remi.16908

This text was automatically generated on 3 January 2023.

All rights reserved 


\section{Editorial: Out of the Big Cities! The Reception of Exiles in Small Immigration Localities}

Éditorial: Hors des grandes villes! L'accueil des exilée's dans les petits milieux d'immigration

Editorial: ¡Fuera de las ciudades! La acogida de los inmigrantes en los pequeños lugares de migración

\section{Anouk Flamant, Aude-Claire Fourot and Aisling Healy}

Translation : Alexia Moyer

We would like to express our gratitude to Camille Schmoll for the coordination work she carried out with us. We are particularly indebted to her for the international dimension of this special issue. Thanks also to the members of the editorial board of the REMI and to Audrey Brosset, its editor, who accompanied and supported us throughout the development of this issue. The cover photograph is the work of Céline Gaille; many thanks to the entire Camigri team for allowing us to reproduce it. A special thank you to the authors and reviewers for their trust and for their positive responses to our invitation to contribute to this issue. Last but not least, Montrealer Alexia Moyer (red line-ligne rouge editorial collective), judiciously translated this introduction thanks to the support of the France Canada Research Fund.

1 The majority of exiled populations reside in cities. Small urban centres and rural areas are more often associated with emigration than immigration. Yet, as the proliferation of newspaper articles ${ }^{1}$ and documentaries ${ }^{2}$ illustrate, the "migration crisis" of 2015 highlighted the rise of multiple and contrasting forms of reception of exiled populations, forced to settle in territories unaccustomed to their presence. Whether marked by anti-migrant demonstrations or, by contrast, supported by the solidarity of the inhabitants, initiated by local actors or imposed by the central state, the reception of exiles outside large urban centres has long remained largely invisible to the social sciences, due to the urban focus at the heart of migration studies. ${ }^{3}$ Moreover, even today this issue remains little discussed in the literature on the "local turn" in the 
governance of migration (Caponio and Borkert, 2010). The articles in this special issue aim to address this relative silence. They ask, who welcomes exiles outside the big cities? How are these populations received? What are the challenges, constraints and specific opportunities for reception in these areas?

2 From these initial questions, ${ }^{4}$ we engage, along with the authors of this special issue, in a sustained reflection on reception outside metropolitan areas. ${ }^{5}$ The terminology used reflects the two intersecting issues central to this study. First, the study of migratory phenomena repeatedly and problematically raises the question of what words to use in referring to populations on the move. The authors favour "migrant", "refugee", "asylum seeker", and "exile" according to their particular approaches, fields of study and those categories of people under consideration. In this editorial, we have used the term "exile" which encompasses the different groups studied by the authors. While the term "migrant" was long considered neutral, it has gradually acquired negative connotations, associated as it has become with disguised economic migration. "Refugee", on the other hand, retains its legitimacy as defined and conferred upon it by the Geneva Convention in 1951 (Akoka, 2020). The term "exile" ultimately allows us to get out of the "migrant" versus "refugee" dichotomy while underlining the multifactorial nature of the reasons behind migration. Further, the term does not stigmatize people according to their administrative and legal statuses while reminding us of the constraints weighing on the mobility of these populations, in particular when they are obliged to settle in small localities that they have not chosen. The term exile therefore makes it possible not to use the terms of those who categorize but to consider the migratory experience of those who live it (Akoka, 2020). Adopting this terminology does not, however, erase the resettlement services and access to rights according to the administrative categories to which the exiles belong, nor does its adoption deny the differences between the institutions and actors who administer them.

The category of seasonal workers has not been included in this special issue. While this population is subject to a controlled territorial mobility (in terms of accommodation and mobility as managed by a specific employer) and experiences foreignness in such new places, it lives it temporarily (although repeatedly) and in a context of labour migration, which is very specific. ${ }^{6}$

4 Moreover, we prefer to qualify these territories, rather than simply designate them "as reception areas outside large urban centres." This designation certainly has the merit of being the most unifying since it encompasses all the expressions used by the authors of this issue to qualify the territories to which their research relate: "French countryside" (Berthomière et al.), "small and medium-sized towns" (Bouagga; Dauphin and Veronis; Gardesse), "transitory spaces" (Martin), "declining spaces" (Gardesse), "rural areas and spaces" (Berthomière et al.; Bouagga), "village" (Martin), "peripheral geographies of the defence of the rights of migrants and refugees" (Schmid-Scott et al.), "areas with low residential attractiveness" (Gardesse), "isolated territories", "fragile spaces" (Arfaoui), "peri-urban" (Berthomière et al.; Deschamps et al.) or even "margins" (Ristic). But, bringing these descriptors together by what they are not could help to essentialize an opposition between metropolises, presented as necessarily cosmopolitan territories versus the "other" territories, spaces by definition homogeneous and only recently and suddenly confronted with migration.

Conversely, the articles brought together here do not fit into an idealized vision of these "other territories" either, a vision that has also been revived in the context of the 
Covid-19 pandemic. Indeed, small urban centres and rural territories have been the object of a resurgence of popularity in public discourse and in the collective imaginary. These are presented as "idyllic" places (Schmid-Scott et al., in this issue) with accompanying lifestyles better suited to safeguarding its inhabitants from the spread of the virus. Not subscribing to a fantasized vision of "small is beautiful", all of the authors of this issue are opposed to the idea that these territories would necessarily be welcoming, offering a peaceful idyll and a common understanding between exiles and their neighbours. Since 2015, demonstrations against exiles have proliferated both in metropolitan areas and outside them (Bock, 2018; Oliver et al., 2020; Deschamps et al., in this issue).

6 Thus, continuing the reflections proposed by Belkhodja and Vatz Laaroussi (2012), as well as by Manço et al. (2012), we have chosen, in this editorial, to qualify these spaces as "small immigration localities." By this expression we mean places where the general population is small, or even very small compared to the nearest metropolises, and where ethnic and racialized minorities as well as people of immigrant background are comparatively few in number. Further, civil society organisations linked to migration along with policies and public services dedicated to reception and integration are all but lacking in the territory. In economic terms, the tertiary sector is comparatively less developed, as are the employment opportunities for newcomers (formal and informal jobs). In terms of housing, vacancy rates are generally higher, and the real estate market is more affordable.

7 By exploring these spaces too often neglected by migration studies (Glick Schiller and Cağlar, 2009) as well as by urban studies (Bell and Jayne, 2009), this special issue offers a more thorough investigation of the "local turn" in the governance of migration by studying the actors - whether they be elected representatives, associations, providers of social housing or volunteers - and the institutions that act "for" (on behalf of their interests, but also sometimes in lieu of their inhabitants) and "in" these territories (by carrying out concrete actions there). This issue also takes an interest in the experiences of exiles, their choices and their journeys far from large metropolises. Finally, the issue's international perspective makes it possible to question the logics that structure a global governance of migration that is essentially inaccessible to these "small localities," although the latter are nevertheless critical links and actors in their own right. Without being an entirely new phenomenon, since 2015, in Europe as in North America, the dynamics of institutionalized distribution of exiles across all national territories have indeed accelerated. As a consequence, the role of actors in less densely populated areas has come under increased scrutiny. Above all, distribution policies outside large metropolises have effects that are both expected (economic dynamism, in particular, as newcomers take up jobs that locals no longer want to do) and unexpected (sustained welcoming dynamics among residents, conflicts, redefinition of the urban migratory route imagined by exiles and difficulties of retaining exiled populations in small localities) by institutional actors.

\section{De-urbanize the Focus on the Reception and Integration of Exiles}

Work on the "local turn" of reception and integration policies has increased over the past decade (among others, Dekker et al., 2015; Fourot, 2015; Caponio et al., 2017). 
Whether in Europe, North America or in so-called "southern" countries, cities and regions have become increasingly active in defining and implementing programs and policies to respond to the challenges posed by and the stakes surrounding migration. Local authorities are therefore claiming a greater say in the governance of migration at the international level, as evidenced in particular by the increase of city networks focused on this topic (Flamant et al., 2021; Oomen, 2020; Lacroix, 2020).

Nevertheless, this work on the local governance of migration has mainly focused on large metropolises. ${ }^{7}$ Several other studies have shown an interest in arrival cities (Saunders, 2010), those openly committed to welcoming, integrating and promoting cultural diversity (White, 2018; Broadhead, 2020), such as Barcelona (Bazurli, 2019; Gebhardt, 2021) or Nantes and Strasbourg (Flamant, 2017 and 2020). Other studies have focused on the dynamics of inhospitality (Dahdah et al., 2018), or on urban policies that are explicitly reluctant regarding the matter of immigration, as in Italy (Ambrosini, 2013), the Netherlands (Uitermark and Duyvendak, 2008) or in the United States (Varsanyi, 2011). Finally, while work on "sanctuary" cities or "refuge" cities has increased in recent years in the global North and South respectively (for example, Furri, 2017; Lasch et al., 2018; Missbach et al., 2018; Moffette and Ridgley, 2018), the literature dealing with pro-migrant activism outside the major immigration centres remains little explored (Schmid-Scott et al., in this issue).

In the end, the literature too often overlooks the part played by actors showing solidarity and offering hospitality in small immigrant localities. In this context, the cases selected by these authors offer much in the way of investigative material, particularly in terms of the reasons behind those selections (Schmiz et al., 2020). To put it another way, the accumulation of studies mainly focusing on big and multi-ethnic cities or on "extreme cases" invites us to enrich the "local turn" literature by diversifying the cases that are studied. It means turning our gaze from large urban metropolises towards other spaces of reception and integration. While some studies have already analysed smaller territories and their relationship to immigration, ${ }^{8}$ the fact remains that the reception of exiles since 2015 in small communities in Europe and North America has not, to our knowledge, been at heart of any such editorial endeavour so far.

11 Thus, by bringing together ten contributions, which adopt various methodological approaches (quantitative, qualitative and ethnographic) and which come out of various disciplinary traditions (geography, sociology, political science, anthropology and economics), this special issue of the REMI sets out to "de-urbanize" studies of migration to understand how contemporary mobility involves the mobilization of actors in these more "peripheral" territories (Belkhodja and Vatz Laaroussi, 2012).

We have gathered contributions with an interest in municipalities such as Gatineau in Québec/Canada, small immigration communities in France (Auvergne, Cévennes, Brittany and the Limousin), but also British counties and cities (Somerset, Devon, Exeter) or Italian villages (Riace, Calabria). These varied perspectives make it possible to go beyond the question of demographic thresholds, as they differ from country to country and according to national experience. ${ }^{9}$ This cumulative case approach is not intended to offer a point-by-point comparison of the territories. Rather, it aims at accounting for the plurality of ways in which hospitality is emerging in the contemporary world, by highlighting both the local specificities and the common dynamics of these territories, in a context where the increased securitization and 
criminalization of immigration policies adopted by states and supranational institutions (Slama, in this issue) have been accompanied by policies of distribution of exiled populations.

\section{From the Dispersion of Exiles to the Revitalization of the Host Territories: Peopling Policies ${ }^{10}$}

13 While dispersion policies of exiles respond to humanitarian logics (Bouagga, in this issue), the latter have above all a dual objective: the "invisibilisation" of exiles but also the revitalisation of territories facing major economic and demographic challenges. All of these long-term distribution policies - most often piloted by states but involving a myriad of local public and private actors - should be considered "peopling policies" (Desage et al., 2014). These "peopling policies" differ by their degree of constraint: "elective" then "coercive" during the dismantling of the "jungle" in Calais (Bouagga, in this issue), but also more discreet, indirect and of an incentive nature, with the implementation of mechanisms aimed at ensuring the sustainability of the integration of exiles via access to the labour market, language learning or the granting of housing dedicated to families (Dauphin and Veronis; Deschamps et al., in this issue).

\section{A Multiscalar Distribution of the "Burden"}

Often legitimized by states in the name of "solidarity" between territories, the policies of dispersal of asylum seekers and refugees have as their main purpose "burden sharing" (Boswell, 2003) and the distribution of "costs" in receiving exiles (Berthomière et al., in this issue). These territorial distribution policies are generally multiscalar, in the sense that they articulate different territorial scales (Arfaoui, in this issue).

First, at the international level, it is a matter of sharing the task of examining asylum applications, such as the number of refugees resettled from one country to another This distribution can take several forms. It is embodied within the European Union by the Dublin Regulation (2013) and is the subject of strong tensions between member states who oppose the methods of distributing populations. ${ }^{11}$ In the North American case, the Safe Third Country Agreement, also a matter of debate, ${ }^{12}$ states that asylum claims made from a land port of entry from the United States are inadmissible in Canada, placing the responsibility on the United States to process the asylum claims of those who have passed by its territory. ${ }^{13}$

16 The distribution of exiles, as an instrument for regulating international migration with the aim of distancing these populations spatially, is also illustrated by the proliferation of centres intended for them. These centres (which are mostly detention centres, even though they are known as reception and integration centres) are intended for exiles both before and after they can make a claim for asylum - as in Australia with offshore camps on Pacific islands (McAdam, 2013) or in Europe with hotspots on the Mediterranean islands (Tazzioli and Garelli, 2020). They do indeed consist of forms of "world encampment" (Agier, 2014). By adopting regulations similar to detention centres, these "hotspots" de facto restrict the mobility of exiles (Bouagga and Barré, 2017; Schmoll, 2020). ${ }^{14}$ 
17 Second, within each country, it is a question of ensuring a more "equitable" distribution between regions. Initiated in Germany in the mid-1970s, the policies of territorial dispersion of asylum seekers have multiplied within European countries, regardless of the number of exiles received (Boswell, 2003). Thus, in France, while the national reception system $\left(\mathrm{DNA}^{15}\right.$ ) for asylum seekers was institutionalized in 2015, the dispersal of exiles across the national territory has been in practice since the 1970s (Kobelinsky, 2010), with an "asylum regionalization procedure" increasing from the 1990s and 2000s (Berthomière et al., in this issue). And yet, it is only over the last ten years that small immigrant localities have become priority targets for the distribution of exiles in France. ${ }^{16}$ Although the accompanying infrastructure could have taken place following proposals from enthusiastic municipalities that a vacant building be transformed into a reception centre (Berthomière et al., in this issue), they are most often decided upon from a distance and prescribed by the prefecture. By not taking local actors or territorial specificities into consideration (Arfaoui; Bouagga, in this issue), these requisitions have sometimes been the source of tensions with elected officials and local populations (Berthomière et al.; Deschamps et al., in this issue).

In Italy, territorial redistribution policies have also been put in place since the beginning of the 2010s. Led by the prefectures and the Ministry of the Interior, the public reception system receives the vast majority of asylum seekers (Ristic, in this issue). But in parallel to this system, and in order to increase reception capacities, the Italian state has set up (and finances) another reception program for refugees and asylum seekers (Sistema di Accoglienza e Integrazione, since October 2020), which is managed by the municipalities. However, among the voluntary municipalities that are part of this national network of cities, more than half are municipalities with less than 5,000 inhabitants, including Riace (Patuzzi et al., 2020).

19 In the UK, the reception system is centralized, but the Home Office contracts out the dispersal of and accommodation for asylum seekers to private service providers. This system has been criticized by several local authorities who not only lament their exclusion from the decision-making process, but also stress the poor territorial distribution of housing and its inferior quality. These tensions are all the more acute because this pattern contrasts with that of refugee resettlement, for which local governments have direct responsibilities in terms of reception (Broadhead, 2020).

Thus, within each regional group, the objective is often to reduce the imbalance between the metropolises and the rest of the territory. This is particularly the case in Canada and Québec where policies for the distribution of immigration have, since the 1980s, sought to settle the refugees selected abroad $^{17}$ outside the big cities, where the overwhelming majority of migrant populations reside (Simard, 1996). As Anyck Dauphin and Luisa Veronis explain in this issue, the resettlement of refugees is mainly based on a dual system of sponsorship: refugees sponsored by the government, previously identified by the Office of the United Nations High Commissioner for Refugees (UNHCR) and refugees sponsored by the private sector (groups of individuals, churches, mosques, etc.). While privately sponsored refugees settle in the same city as their sponsors, the mobility of government-assisted refugees is more restricted since they are resettled in localities identified by the state. ${ }^{18}$

21 While the reception of exiles in less densely populated areas can be considered an instrument of population control (Gardesse, in this issue), these policies are also part of 
a more general trend of attempts to control urban metropolises, increasingly dense and immense across the world (Brueckner, 2000; Habibi and Asadi, 2011).

\section{An Opportunity for Economic and Demographic Development} considered "desirable" (Agier, 2014). The opening of reception and orientation centres (CAO) in France, following the evacuation of the Calais "jungle" at the end of 2016, nevertheless reminds us that the concepts of "desirability" and "(un)desirability" evolve over time..$^{20}$ While reception refusal may have occurred in several towns and villages in France (Tardis, 2019), several articles in this special issue (Arfaoui; Berthomière et al.; Gardesse; Martin; Ristic) show that this regional distribution can constitute a strong opportunity for local actors aiming to maintain certain public services (schools, transport, etc.), the collection of rents for vacant buildings or even opportunities for economic revitalization. In Italy in particular, the installation of temporary reception centres in the South, in a bid to repurpose neglected infrastructures, has created a substantial "welcoming economy" in terms of jobs, or maintenance of public services (Schmoll, 2020; Ristic, in this issue). Conceived as revitalization tools, such peopling policies have found favour with local actors to the point of arousing forms of competition to attract these populations (Ristic, in this issue).

\section{What are the Specificities of Reception and Integration in Small Immigration Localities?}

Beyond a better understanding of the national parameters of asylum and refugee resettlement and their appropriation (or not) by local actors, this special issue also 
contributes to the analysis of the specificities of reception and integration in small immigrant localities. The articles explore the profiles of those who are involved in receiving exiles. On the one hand, they offer a renewed analysis of local pro-migrant activism when it is generally understood as urban (as in Monforte and Dufour, 2011). On the other hand, these contributions underline the unprecedented proximity between actors with diverse and often diverging backgrounds (whether activists or professionals). This reception work is, as a result, not without rivalries. In addition to the conflicts between the different levels of government around their responses to and implementation of peopling policies, the articles bring lesser-known forms of friction between volunteers and "settlement practitioners" to the fore. Finally, the articles gathered here offer a renewed analysis of the experience of the multiple temporalities that meet (and sometimes collide) for both welcomers and exiles. Last but not least, several articles provide space for those exiled populations to describe these dispersion policies. Too often reduced to silence, listening to exiles' voices make it possible to understand the effects of these practices of control, but also reveal the mechanisms of resistance at work on the part of exiles.

\section{Sociology of Activists in Small Immigrant Localities}

The articles gathered here continue the existing reflections on the role of organizations (associations for the defence of foreigners' rights, activist groups, unions, etc.) and volunteers in supporting undocumented migrants or asylum seekers (among others Siméant, 1998; Valluy, 2008). If the authors in this issue more expectedly underline the place of the Church as well as left and far-left movements in support of these populations (Pette and Eloire, 2016), the originality of their texts lies in the attention paid to the residents who have "discovered" migration during the establishment of an accommodation centre in their small town or village (Berthomière et al., in this issue). These hospitality "novices" become involved alongside volunteers who have been familiar with the cause of newcomers for decades. In Auvergne, anarchist activists are campaigning alongside neo-rural retirees (Arfaoui, in this issue). In the Cévennes, volunteers from the Reformed Church, including retired teachers, rub shoulders with far-left activists (Martin, in this issue). This trend is not specific to France. Across the Channel and across the Atlantic, the availability of retirees plays a central role in the functioning of rural sanctuary spaces (Schmid-Scott et al., in this issue) and as support groups for Syrian refugees (Dauphin and Veronis, in this issue). Geographical proximity, when associated with a willingness to welcome, facilitates the involvement of residents in support groups, despite the diversity of their sociological profiles and their political orientations. These welcoming dynamics are nevertheless not without a certain degree of rivalry between these same actors.

\section{Competition between Actors Involved in the Reception of Exiles}

Beyond activists, the articles focus on the concrete roles of all actors involved in the reception of exiles (management associations, social workers, volunteers, local and national elected officials, municipal officials or agents of decentralized state institutions, providers of social housing, beneficiaries, etc.). By identifying the diversity 
of their interests, the contributions gathered here analyse cooperation, but also rivalry between actors. This is particularly the case of militant groups often in competition or even in conflict with the resettlement associations that they consider too "strict" in their management of isolated minors and not sufficiently critical of the policies of national immigration (Martin, in this issue). The impact of the administrative categories (for example asylum seekers, refugees, rejected asylum seekers) on the different forms of support for exiles is at the centre of several debates. Involved in these rivalries, volunteers come to question the conditions of reception and its articulation within the rule of law. In this vein, Daniela Ristic analyses how forms of civil disobedience arose in Limousin and Calabria in defence of an unconditional welcome that opposes national control policies. Conversely, when social workers or municipalities claim to be responsible for reception, these actors often deplore the failure on the part of volunteers to take into account the context in which they work. Further, they disapprove of the actions of volunteers that they perceive as being too "demanding" or too "amateur", which hamper them in their support of exiles (Gardesse, in this issue). These confrontations between volunteers and professionals carry greater weight as they take place in a space where social interconnections are less anonymous than in large cities (Berthomière et al., in this issue).

\section{The Multiplicity of Reception Timelines}

The articles gathered here also allow us to better understand the multiple temporalities experienced by exiled populations and by those actors involved in reception: an emergency timeframe, which brings together multiple and varied actors in a circumscribed way, as was the case for the evacuation of Calais (Bouagga, in this issue); prolonged administrative procedures that increase the vulnerability of exiles (Deschamps et al., in this case); the temporality of asylum marked by constant uncertainty, boredom and idleness without any real possibility of working in France; or even the temporality of the actions of social workers whose feeling of powerlessness is strong, caught as they are between procedures, constraints and reconfiguration of social work (Berthomière et al., in this issue).

Faced with these imposed temporalities, actors nevertheless resist and adapt. This is particularly the case for some hospitality actors who promote a "temporality of protest", in which welcoming takes place in a timeframe other than that which has been imposed by the state, at their own personal cost (Arfaoui; Berthomière et al., in this issue). In the same vein, providing exiles with jobs (such as in Riace, see Ristic, in this issue) makes it possible for them to do something other than wait, in expectation of and dependence upon the state. Such work facilitates their exchanges with inhabitants and other exiles as well as offering them new capacities to act upon their migratory journey. This is also the case with language learning. In Québec and Canada, volunteers have mobilized to compensate for the inadequacies of the state by offering French lessons directly at home (Dauphin and Veronis, in this issue). Understanding these different temporalities thus makes it possible to better highlight the contradictions and tensions that structure the reception of exiles from small immigrant localities, in particular around the difficulties caused by a lack of public transport, the distance to public services and shops, or the distance from other social, ethnic and religious networks. 


\section{Listening to the Voices of Exiles to Understand their Experiences}

Finally, this special issue provides a better understanding of how the beneficiaries of these policies - who are more often spoken for than are granted an opportunity to speak - experience reception in small immigration localities. It thus offers a more detailed portrait of the effects of these distribution policies on exiles. The article by Catherine Deschamps, Laetitia Overney, Jean-François Laé and Bruno Proth traces contrasting journeys in such places. To analyse the impressions of exiles about their new lives, the authors pay particular attention to family dynamics over migratory routes as well as to their initial visions of the country of immigration. Anyck Dauphin and Luisa Veronis, for example, recount the disappointment experienced by some exiles who have to learn French in Québec when they consider English to be a better fit, the language they associate with success and social advancement. Daniela Ristic looks back in detail at the first impressions of exiles as they got off the buses from Calais. The exiles speak of their feelings of exclusion and the difficulties they have experienced the absence of other foreigners in the municipality, the absence of people speaking the same language, limited means of transport, their desire to live in the city - which illustrates how these distribution policies can contradict the migratory routes imagined and constantly redefined by exiles (Schmoll, 2020). This isolation also experienced in the municipality of Ambert (Arfaoui, in this issue), in the Dordogne area (Deschamps et al., in this issue) or in the small territories studied by Camille Gardesse requires the time and talents of social workers and volunteers. While the exiles frequently stress how a more "peaceful" installation can take shape in territories further removed from police pressure and the violence of urban camps, the absence of public transport and often cobbled-together solutions (in particular the use of personal vehicles) offered by social workers and volunteers come up on several occasions in these case studies and are presented as a hindrance to the integration of exiles and a risk of exhaustion for caregivers in these small localities. Finally, these articles also reveal the resistance and resilience capacities of exiles in the face of these dispersion policies. While some refuse to board the buses in Calais (Bouagga, in this issue), others accept this exclusion only for the duration of the procedure, considering that they have more chances to regularize their stay by "playing the game" for the benefit of the authorities, while planning their return to large urban centres later on. Above all, these exiles address their wait, as demonstrated by several life narratives collected in the scope of this issue (Deschamps et al.; Ristic), by claiming certain rights (in particular of work for asylum applicants) in their place of residence.

\section{The Articles}

31 This special issue is divided into three parts. First, it puts the policies of dispersal of exiled populations into context. Yasmine Bouagga's article focuses on the establishment of reception and orientation centres, starting with an ethnographic observation of the evacuation of the Calais "jungle." This research highlights how public action aimed at exiles in France took shape in the form of emergency measures, with dimensions of both security and humanitarianism. 

involved in supporting refugees are at the centre of the article by Amanda SchmidScott, Emma Marshall, Nick Gill and Jen Bagelman. Using a participatory methodology, these authors focus on the reception capacities of rural territories seeking to be "sanctuary" territories. They have drawn up a typology of this rural activism, characterized by a more general form of support offered to refugees, by the centralization of aid, by longer and more constant support from volunteers and by social relations that offer individuals more diversified paths and trajectories than in large urban centres. The authors then conclude that sanctuary reception in rural areas, characterized by stable and lasting commitments on the part of local activists, could offer better structured, and more lasting, assistance to refugees, both now and in future.

36

Élise Martin analyses the reception arrangements in various villages of the Cévennes, a region characterized by a long tradition of hospitality, and now built around Protestant parishes and left or far-left activists committed to the needs of exiles. The author shows how these actors insist on unconditional welcome, a position facilitated by a context of many vacant homes. Here again, this research questions the sustainability of this reception by highlighting how these places are spaces of "respite" for exiles, before the latter reach other more connected urban centres, providing jobs and facilitating community relations. 

their migration paths and their experience, and allow the experiences of exiles to be situated within the dynamics of control and settlement. Anyck Dauphin and Luisa Veronis look at the resettlement of Syrian refugees in Gatineau (Québec), a city located right next to Ottawa (Ontario), where the English language is predominant, and which is also the national capital of Canada. Through participatory research, these authors question the impact of private and state sponsorship on refugee resettlement and show that the initial profile of the populations received, coupled with the reception conditions in Gatineau, is a determining factor in their capacities to integrate. For example, state-sponsored Syrian refugees (and women in particular) encountered much greater difficulties than Syrian refugees sponsored by the private sector, who have benefited from more sustained support. This text therefore invites us to grasp the plurality of paths prior to resettlement and recalls the importance of moving beyond a monolithic vision that obscures the uniqueness of the experiences of each exile.

The article by Catherine Deschamps, Laetitia Overney, Jean-François Laé and Bruno Proth focuses on the early days of exile and those men and women who leave the more precarious places of the Parisian camps and Calaisis and discover new settlements. By analysing the experiences of these exiles in three types of accommodation, the authors highlight the importance of the associative network and the willingness of local residents to welcome exiles. Without their help, settling in is made impossible due to the difficulties of accessing transportation and public services. In any case, the authors see the lack of the right to work as the main barrier to a peaceful and inclusive installation. This restriction highlights, once again, a temporality of asylum marked by recurring uncertainties, which makes populations even more vulnerable.

Finally, the perspective offered by Daniela Ristic is twofold since it presents the journey of exiles arriving in two rural areas, Limousin in France and Calabria, in particular with the much-publicized case of Riace, in Italy. By giving a voice to exiles, the author offers an analysis of "innovative solidarities" and "disobedient" practices in favour of exiled populations in territories facing the challenges of requalification.

These research articles are supplemented by a legal chronicle by Serge Slama on the reconfiguration of the national reception system (DNA) in France, and in particular its territorial decentralization. The article reveals how, since the asylum reform in 2015, the state strategy towards asylum seekers has meant an increase in the number of available places. These places, however, are increasingly subject to regionalization (led by regional prefects and $\mathrm{OFII}^{21}$ territorial delegations) and are dispersed throughout the territory. However, these dynamics of decentralization reveal the multiplication of structures: CAO, ${ }^{22}$ CAES (situation examination centres), municipal centres in relation to the CADA ${ }^{23}$ initially planned as the main mechanism of the national asylum system. Above all, with the emergence of new administrative categories, such as Dubliners and rejected asylum seekers, the state is increasing the number of centres aimed at detaining populations before expelling them. These successive reforms of the right to asylum show the extent to which the protection it offers has been reduced over the years while the search for the "bogus" asylum seeker constitutes a cornerstone of immigration and social policy.

41 Finally, the photography essay was produced by William Berthomière, Céline Gaille and Christophe Imbert. Entitled "By Pure Chance": Anchors and Intertwined Destinies of New Inhabitants (Ariège 2017-2019)", this work offers a look at the new inhabitants of 
Ariège. They share a trajectory marked by international mobility that is either voluntary or enforced. The varied and multiple journeys undertaken by those who have settled in Ariège are made manifest by an attachment to such places as well as plural activist investments.

\section{BIBLIOGRAPHY}

Agier Michel (Dir.) (2014) Un monde de camps, Paris, La Découverte.

Akoka Karen (2020) L'asile et l'exil. Une histoire de la distinction réfugiés/migrants, Paris, La Découverte.

Alexander Michael (2003) Local Policies Toward Migrants as an Expression of Host-Stranger Relations: A Proposed Typology, Journal of Ethnic and Migration Studies, 29 (3), pp. 411-430.

Ambrosini Maurizio (2013) We Are Against a Multi-Ethnic Society: Policies of Exclusion at the Urban Level in Italy. Ethnic and Racial Studies, 36 (1), pp. 136-155.

Barou Jacques, Maguer Annie, Foroni Fabrice et Rémy Aude (2009) Histoire de l'immigration en Auvergne, Hommes \& migrations, 1278, [en ligne]. URL : https://journals.openedition.org/ hommesmigrations $/ 247$

Basok Tanya (2004) Post-National Citizenship, Social Exclusion and Migrants Rights: Mexican Seasonal Workers in Canada, Citizenship Studies, 8 (1), pp. 47-64.

Bazurli Raffaele (2019) Local Governments and Social Movements in the "Refugee Crisis": Milan and Barcelona as "Cities of Welcome", South European Society and Politics, 24 (3), pp. 343-370.

Belkhodja Chedly et Vatz Laaroussi Michèle (Dirs.) (2012) Immigration hors des grands centres: Enjeux, politiques et pratiques dans cinq États fédéraux, Paris, L'Harmattan.

Bell David and Jayne Mark (2009) Small Cities? Towards a Research Agenda, International Journal of Urban and Regional Research, 33 (3), pp. 683-699.

Bock Joseph (2018) Migrants in the Mountains: Shifting Borders and Contested Crisis Experiences in Rural Germany, Sociology, 52 (3), pp. 569-586.

Bonifacio Glenda and Drolet Julie (Eds.) (2016) Canadian Perspectives on Immigration in Small Cities, Cham, Springer International Publishing.

Bontemps Véronique, Makaremi Chowra et Mazouz Sarah (Dirs.) (2018) Entre accueil et rejet : ce que les villes font aux migrants, Lyon, Le Passager Clandestin.

Boswell Christopher (2003) Burden-Sharing in the European Union: Lessons From the German and UK Experience, Journal of Refugee Studies, 16 (3), pp. 316-335.

Bouagga Yasmine (Dir.) et Barré Céline (Collab.) (2017) De Lesbos à Calais : comment l'Europe fabrique des camps, Neuvy-en-Champagne, Le Passager Clandestin.

Broadhead Jacqueline (2020) Building Inclusive Cities: Reflections From a Knowledge Exchange on the Inclusion of Newcomers by UK Local Authorities, Comparative Migration Studies, 8 (14), 
[online]. URL: https://comparativemigrationstudies.springeropen.com/articles/10.1186/ s40878-020-0172-0

Brueckner Jan K. (2000) Urban Sprawl, International Regional Science Review, 23 (2), pp. 160-171.

Caponio Tiziana (2017) Immigrant Integration Beyond National Policies? Italian Cities'

Participation in European City Networks, Journal of Ethnic and Migration Studies, 44 (12), pp. 1-17.

Caponio Tiziana and Borkert Maren (Eds.) (2010) The Local Dimension of Migration Policymaking, Amsterdam, Amsterdam University Press.

Caponio Tiziana, Scholten Peter et Zapata Barrero Ramon (2017) Théorisation du " virage local» dans un cadre d'analyse fondé sur la gouvernance à niveaux multiples. Étude de cas axée sur les politiques concernant les immigrants, Revue Internationale des Sciences Administratives, 83 (2), pp. 245-250.

Cordier-Montvenoux Camille (2015) Un accueil méfiant : les étrangers dans le Puy-de-Dôme au début du XXe siècle (1900-1940), Migrance, 45-46, pp. 135-148.

Cremaschi Marco, Albanese Flavia and Artero Maurizio (2020) Migrants and Refugees: Bottom-Up and DIY Spaces in Italy, Urban Planning, 5 (3), pp. 189-199, [online]. URL: https://

www.cogitatiopress.com/urbanplanning/article/view/2921

Cvetkovic Anita (2009) The Integration of Immigrants in Northern Sweden: A Case Study of the Municipality of Strömsund, International Migration, 47 (1), pp. 101-131.

Dahdah Assaf, Audren Gwenaelle et Bouillon Florence (2018) La ville (in)hospitalière : parcours scolaire et résidentiel d'une famille syrienne à Marseille, Espaces et société, 172-173, pp. 73-91.

Dahinden Janine (2009) Are we all Transnationals Now? Network Transnationalism and Transnational Subjectivity: The Differing Impacts of Globalization on the Inhabitants of a Small Swiss City, Ethnic and Racial Studies, 32 (8), pp. 1365-1386.

De Graauw Els and Vermeulen Floris (2016) Cities and the Politics of Immigrant Integration: A Comparison of Berlin, Amsterdam, New York City, and San Francisco, Journal of Ethnic and Migration Studies, 42 (6), pp. 989-1012.

Dekker Rianne, Emilsson Henrik, Krieger Bernhard and Scholten Peter (2015) A Local Dimension of Integration Policies? A Comparative Study of Berlin, Malmö, and Rotterdam. International Migration Review, 49 (3), pp. 633-658.

Del Biaggio Cristina, Giannetto Leila et Noûs Camille (Coords.) (2020) Réfugiée's et montagne, Revue de géographie alpine, 108 (2), pp. 1-9.

Desage Fabien, Morel Journel Christelle et Sala Pala Valérie (Éds.) (2014) Le peuplement comme politiques, Rennes, Presses Universitaires de Rennes.

Downing John (2016) Influences on State-Society Relations in France: Analysing Voluntary Associations and Multicultural Dynamism, Co-Option and Retrenchment in Paris, Lyon and Marseille, Ethnicity, 16 (3), pp. 452-469.

Escafré-Dublet Angéline and Lelévrier Christine (2018) Governing Diversity Without Naming it: An Analysis of Neighbourhood Policies in Paris, European Urban and Regional Studies, 26 (3), pp. 283-296.

Flamant Anouk (2020) The Local Turn in Integration Policies: Why French Cities Differ, Ethnic and Racial Studies, 43 (11), pp. 1981-2000.

Flamant Anouk (2017) L'incomplète construction des politiques municipales de lutte contre les discriminations raciales, Revue internationale de politique comparée, 24 (3), pp. 257-291. 
Flamant Anouk, Fourot Aude-Claire et Healy Aisling (Éds) (2021) Villes et migrations à l'ère des réseaux : investissements, mobilisations, et usages des réseaux de villes dans l'accueil des populations migrantes, Paris, Éditions PUCA.

Fourot Aude-Claire (2015) "Bringing Cities Back In" To Canadian Political Science: Municipal Public Policy and Immigration, Canadian Journal of Political Science, 48 (2), pp. 413-433.

Fourot Aude-Claire (2013) L'intégration des immigrants : cinquante ans d'action publique locale, Montréal, Presses de l'Université de Montréal.

Fourot Aude-Claire (2011) Immigrants en banlieue et politiques publiques municipales : Le cas Lavallois (Québec, Canada), Administration publique du Canada, 54 (1), pp. 97-119.

Furri Filippo (2017) Villes-refuge, villes rebelles et néo-municipalisme, Plein droit, 115 (4), pp. 3-6. Gardesse Camille, Lelévrier Christine (2020) Refugees and Asylum Seekers Dispersed in NonMetropolitan French Cities: Do Housing Opportunities Mean Housing Access?, Urban planning, 5 (3), pp. 138-149.

Gebhardt Dirk (2021) Ambitions municipalistes et engagement à long terme. Quelques leçons à tirer de l'action de Barcelone via le réseau Eurocities, in Anouk Flamant, Aude-Claire Fourot et Aisling Healy Éds., Villes et migrations à l'ère des réseaux : investissements, mobilisations et usages des réseaux de villes dans l'accueil des populations migrantes, Paris, Éditions du PUCA, pp. 191-207.

Glick Schiller Nina and Çağlar Ayse (2009) Towards a Comparative Theory of Locality in Migration Studies: Migrant Incorporation and City Scale, Journal of Ethnic and Migration Studies, 35 (2), pp. 177-202.

Good Kristin (2009) Municipalities and Multiculturalism: The Politics of Immigration in Toronto and Vancouver, Toronto, University of Toronto Press.

Habibi Sara and Asadi Nematollah (2011) Causes, Results and Methods of Controlling Urban Sprawl, Procedia Engineering, 21 (133-141), [online]. URL: https://www.sciencedirect.com/science/ article/pii/S1877705811048302?via\%3Dihub

Kirszbaum Thomas (Dir.) (2015) En finir avec les banlieues? Le désenchantement de la politique de la ville, La Tour-d'Aigues, Éditions de l'Aube.

Kobelinsky Carolina (2010) L'accueil des demandeurs d'asile. Une ethnographie de l'attente, Paris, Éditions du Cygne.

Lacroix Thomas (2020) Réseaux des villes hospitalières : un panorama global, E-migrinter, 20, [en ligne]. URL : https://journals.openedition.org/e-migrinter/2281

Lasch Christopher, Chan Linus, Eagly Ingrid, Haynes Dina Francesca, Lai Annie, Mc Cormick Elisabeth and Stumpf Juliet (2018) Understanding "Sanctuary Cities", Boston College Law Review, 59 (5), pp. 5-29, [online].URL: https://lawdigitalcommons.bc.edu/cgi/viewcontent.cgi? article $=3686 \&$ context $=$ bclr

Litcher Daniel (2012) Immigration and the New Racial Diversity in Rural America, Rural Sociology, 77 (1), pp. 3-35.

Macklin Audrey (2003) The Value(s) of the Canada-Us Safe Third Country Agreement, Caledon Institute of Social Policy, [online]. URL: https://ssrn.com/abstract $=557005$

Manço Altay (2012) La Belgique, in Chedly Belkhodja et Michèle Vatz Laaroussi Dirs., Immigration hors des grands centres : Enjeux, politique et pratiques dans cinq États fédéraux, Paris, L'Harmattan, pp. 30-36. 
Manço Altay, Gertnerova Andrea, Vatz Laaroussi Michèle et Bolzman Claudio (2012) Le local et l'immigré. Intégration des migrants hors des « grands centres » : position des problématiques et enjeux, in Chedly Belkhodja et Michèle Vatz Laaroussi Dirs., Immigration hors des grands centres : Enjeux, politique et pratiques dans cinq États fédéraux, Paris, L'Harmattan, pp. 97-122.

Mayer Margit (2017) Cities as Sites of Refuge and Resistance, European Urban and Regional Studies, 25 (3), pp. 232-249.

McAdam Jane (2013) Australia and Asylum Seekers, International Journal of Refugee Law, 25 (3), pp. $435-448$

Meier Sabine (2018) Being Accommodated, Well Then? "Scalar Narratives" on Urban Transformation and Asylum Seekers' Integration in Mid-Sized Cities, Urban Planning, 3 (4), pp. 129-140.

Michalon Bénédicte et Morice Alain (Coords.) (2008) Travailleurs saisonniers dans l'agriculture européenne, Études rurales, 182.

Missbach Antje, Adiputera Yunizar and Prabandari Atin (2018) Is Makassar a "Sanctuary City"? Migration Governance in Indonesia After the "Local Turn", Austrian Journal of South-East Asian Studies, 11 (2), pp. 199-216.

Moffette David and Ridgley Jennifer (2018) Sanctuary City Organizing in Canada: From Hospitality to Solidarity, Migration and Society, 1 (1), pp. 147-155.

Monforte Pierre and Dufour Pascale (2011) Mobilizing in Borderline Citizenship Regimes: A Comparative Analysis of Undocumented Migrants' Collective Actions, Politics \& Society, 39 (2), pp. 203-232.

Myrberg Gunnar (2017) Local Challenges and National Concerns: Municipal Level Responses to National Refugee Settlement Policies in Denmark and Sweden, International Review of Administrative Sciences, 83 (2), pp. 322-339.

Oliver Caroline, Dekker Rianne, Geuijen Karin and Broadhead Jacqueline (2020) Innovative Strategies for the Reception of Asylum Seekers and Refugees in European Cities: Multi-Level Governance, Multi-Sector Urban Networks and Local Engagement, Comparative Migration Studies, 8 (30), [online]. URL: https://comparativemigrationstudies.springeropen.com/articles/10.1186/ s40878-020-00189-y

Oomen Barbara (2020) Decoupling and Teaming up: The Rise and Proliferation of Transnational Municipal Networks in the Field of Migration, International Migration Review, 54 (3), pp. 913-939.

Patuzzi Liam, Andriescu Monica and Piettropolli Antonio (2020) Building Welcome From the Ground Up. European Small and Rural Communities Engaging in Refugee Resettlement, Brussels, Migration Policy Institute.

Pette Mathilde et Eloire Fabien (2016) Pôles d'organisation et engagement dans l'espace de la cause des étrangers : L'apport de l'analyse des réseaux sociaux, Sociétés contemporaines, 101 (1), pp. 5-3.

Preibisch Kerry (2004) Migrant Agricultural Workers and Processes of Social Inclusion in Rural Canada: Encuentros and Desencuentros, Canadian Journal of Latin American \& Caribbean Studies, 29 (57/58), pp. 203-239.

Saunders Doug (2010) Arrival City: The Final Migration and Our Next World, Toronto, Knopf Canada.

Schmiz Antonie, Felgentreff Carsten, Franz Martin, Paul Marcel, Pott Andreas, Räuchle Charlotte and Schrader Sebastian (2020) Cities and Migration. Bibliometric Evidence From a Spatially 
Biased Field of Knowledge Production, Geographical Review, [online]. URL: https://

www.tandfonline.com/doi/full/10.1080/00167428.2020.1812070

Schmoll Camille (2020) Les damnées de la mer. Femmes et frontières en Méditerranée, Paris, La

Découverte.

Simard Myriam (1996) La politique québécoise de régionalisation de l'immigration : enjeux et paradoxes, Recherches sociographiques, 37 (3), pp. 439-469.

Siméant Johanna (1998) La cause des sans-papiers, Paris, Presses de Sciences Po.

Tardis Mathieu (2019) Une autre histoire de la « crise des réfugiés ». La réinstallation dans les petites villes et les zones rurales en France, Études de l'Ifri.

Triandafyllidou Anna and Nalbandian Lucia (2020) Covid-19 and the Transformation of Migration and Mobility Globally. "Disposable" and "Essential": Changes in the Global Hierarchies of Migrant Workers after COVID-19, IOM Publications, [online]. URL: https://publications.iom.int/fr/system/ files/pdf/disposable-and-essential.pdf

Uitermark Justus and Duyvendak Jan Willem (2008) Civilising the City: Populism and Revanchist Urbanism in Rotterdam, Urban Studies, 45 (7), pp. 1485-1503.

Valluy Jérôme (2008) Sociologie politique de l'accueil et du rejet des exilés, Mémoire d'habilitation à diriger des recherches, Paris, Université Sorbonne.

Varsanyi Monica (2011) Neoliberalism and Nativism: Local Anti-Immigrant Policy Activism and an Emerging Politics of Scale, International Journal of Urban and Regional Research, 35 (2), pp. 295-311.

Vertovec Steven (2007) Super-Diversity and Its Implications, Ethnic and Migration Studies, 30 (6), pp. 1024-1054.

Tazzioli Martina and Garelli Glenda (2020) Containment Beyond Detention: The Hotspot System and Disrupted Migration Movements Across Europe, Environment and Planning D: Society and Space, 38 (6), pp. 1009-1027.

Walton-Roberts Margaret (2005). Regional Immigration and Dispersal: Lessons From Small- and Medium-Sized Urban Centres in British Columbia, Canadian Ethnic Studies, 37 (3), pp. 12-34.

White Bob (Ed.) (2018) Intercultural Cities. Policy and Practice for a New Era, Londres, Palgrave Macmillan.

Wulff Maryann, Carter Tom, Vineberg Rob and Ward Stephen (2008) Special Issue: Attracting New Arrivals to Smaller Cities and Rural Communities: Findings From Australia, Canada and New Zealand, Journal of International Migration and Integration, 9 (2), pp. 119-124.

\section{NOTES}

1. For example, Le Touzet Jean-Louis (2020) Dans le Vercors, accueillir les migrants à durée indéterminée, Médiapart, September 15; or La Gazette des communes (2020) Migrants : comment les territoires ont pris le relais de l'État, La gazette des communes, January, [online]. URL : https:// www.lagazettedescommunes.com/dossiers/migrants-comment-les-territoires-ont-pris-le-relaisde-letat/

2. Several documentaries shed light on these questions: As it concerns Riace, see Shu Aiello and Catherine Catella (2017) Un paese di Calabria; on Normandie, Ariane Doublet (2018) Les réfugiés de 
Saint-Jouin; on the Roya Valley, Cédric Herrou (2018) Libre; on the Briançonnais region, Laetitia Cuvelier and Isabelle Mahenc (2019) Déplacer les montagnes.

3. Note that historians have produced numerous studies on migration in rural areas. See, for example, the two issues of Hommes \& migrations in 2008 ( $\left.\mathrm{n}^{\circ} 1273\right)$ and 2009 ( $\left.\mathrm{n}^{\circ} 1278\right)$ devoted to migration in France, several articles of which deal with rural areas, such as Barou et al. (2009) in Auvergne. On the same region, see also the study by Cordier-Montvenoux (2015). This work reminds us that these small localities have a welcoming past and trajectory.

4. This issue emerged out of sessions of the seminar «Les villes européennes et l'accueil des migrants » organised in 2018 in the context of a PUCA research initiative «Villes et réseaux de villes face à la question migratoire » (2016-2019) led by Aisling Healy.

5. However, the latter can also be "metropolitanised" in the sense that the actors of these territories are mobile and can interact with those of neighbouring metropolises.

6. Whether in North America or Europe, migrant agricultural workers remain invisible populations (Michalon and Morice, 2008), whose rights, otherwise limited, are often violated (Basok, 2004). These workers have limited interactions with local residents (Preibisch, 2004). They are minimally accepted, because they carry out arduous tasks in difficult conditions that locals themselves are not willing to perform (Schmid-Scott et al., in this issue).

7. Such as Amsterdam, Rome, Tel-Aviv and Paris (Alexander, 2003), or Paris (Escafré-Dublet and Lelévrier, 2018), Lyon and Marseille (Downing, 2016), welcoming "super diversity" (Vertovec, 2007), with a large population born abroad and from ethnic minorities as the statistics of their respective countries - Toronto, Vancouver (Good, 2009) and Montreal (Fourot, 2013), Milan and Turin (Caponio, 2017), Berlin, Malmö and Rotterdam (Dekker et al., 2015), or Berlin, Amsterdam, New York and San Francisco (De Graauw and Vermeulen, 2016).

8. Among others, mountain areas (Del Biaggio et al., 2020), small towns and rural areas (Wulff et al., 2008; Cvetkovic, 2009; Dahinden, 2009; Litcher, 2012; Bonifacio and Drolet, 2016; Cremaschi et al., 2020), medium-sized towns (Walton-Roberts, 2005; Myrberg, 2017; Meier, 2018; Gardesse and Lelévrier, 2020), or suburban towns (Fourot, 2011; Kirszbaum, 2015).

9. According to Anyck Dauphin and Luisa Veronis (in this issue), a mid-sized city in Canada has a population of between 500,000 and 1 million. In France, INSEE precisely defines the terms "small town" and "medium town" according to demography, between 2,000 and 20,000 inhabitants, and between 20,000 and 100,000 inhabitants, respectively. In the Netherlands, an average city does not exceed the threshold of 50,000 inhabitants (Meier, 2018). In Belgium, it is the history of the locality or of the forms of political and economic recognition that qualifies as a city; the latter is therefore not linked to demographic thresholds (Manço, 2012). In addition to these national differences, we must not overlook the disagreements (including internal) that may exist between researchers and political and social actors (Bonifacio and Drolet, 2016).

10. For "politiques de peuplement."

11. This regulation stipulates that the state that has to examine the asylum application is the first country in the European Union in which the asylum seeker has given their biometric data.

12. Canada has been a strong supporter of this deal given the fact that there are far more asylum seekers in the United States than the other way around. The agreement was not acted upon until after September 11, 2001, after Canada agreed, in return, to enhance border protection and information-sharing measures with the United States (Macklin, 2003).

13. The Canadian Federal Court ruled in 2020 that returning asylum seekers to the United States violates the Canadian Charter of Rights and Freedoms and concludes that the United States cannot be considered a "safe" country. The Canadian government has, however, appealed this decision.

14. Whatever the exiles' journey, that is to say the displacement to other places or the expulsion of those who have been denied the right to asylum and/or who are in an irregular situation.

15. For "Dispositif national d'accueil." 
16. The territorial distribution of Calais exiles in 2015-2016 was not done exclusively outside the metropolises. Some of them were sent to bigger cities (Slama, in this issue). However, the search for accommodation has led the French government to diversify the destination territories, in particular by integrating many very small towns and rural areas into its policy.

17. And not asylum seekers. Unlike European countries, Canada processes few asylum applications even though these increased significantly during the Trump presidency.

18. In Québec, the provincial government has designated thirteen host cities, including Gatineau, a city analysed by Anyck Dauphin and Luisa Veronis in this issue.

19. And this despite the mobility and employment difficulties that may be encountered by exiles in these territories (Tardis, 2019).

20. The Covid-19 pandemic may also have led to a change in representations of the "desirability" of exiles by showing their essential role in the food supply, as well as in the health and social services sector (Triandafyllidou and Nalbandian, 2020).

21. L'Office Français de l'Immigration et de l'Intégration.

22. Centre d'accueil et d'orientation (France).

23. Reception Centre for Asylum Seekers (France).

\section{INDEX}

Mots-clés: accueil, exilés, petits milieux d'immigration, politiques de dispersion, peuplement, redynamisation territoriale, militantisme pro-migrants, temporalités, expériences vécues Keywords: reception, exiles, small immigration localities, dispersal policies, peopling, territorial revitalisation, pro-migrant activism, timelines, lived experiences

Palabras claves: acogida, inmigrantes, pequeñas áreas de inmigración, políticas de dispersión, asentamiento, revitalización territorial, activismo pro-migrante, temporalidades, experiencias vividas

\section{AUTHORS}

\section{ANOUK FLAMANT}

Lecturer in political science, INSHEA/UPL/EA Grhapes, Triangle Research Associate, Université Paris Lumières, 58-60 avenue des Landes, 92150 Suresnes; anouk.flamant@inshea.fr

\section{AUDE-CLAIRE FOUROT}

Associate Professor, Department of Political Science, Simon Fraser University, 8888 University Drive, Burnaby, BC V5A 1S6, Vancouver, Canada; afourot@sfu.ca

\section{AISLING HEALY}

Lecturer in political science, DEPT, Triangle Laboratory, Jean Monnet University, ENS de Lyon, Descartes site, Bât. D4, 15 parvis René Descartes, 69342 Lyon cedex; aisling.healy@univ-stetienne.fr 